Jap. J. M. Sc. \& Biol., 12, 39-54, 1959

\title{
SOME ASPECTS OF VARIATIONS OF PASTEURELLA PESTIS \\ I. THE THIRD COLONIAL FORM OF PASTEURELLA PESTIS
}

\author{
AKIRA WAKE \\ Department of Bacteriology, National Institute of Health, Tokyo \\ (Received: April 7th, 1959)
}

The classification of the subspecies of Pasteurella pestis has been made from a viewpoint of biological reactions on one hand and from a viewpoint of virulence on the other hand. The former viewpoint is, for example, represented by the classification employing the glycerol-fermentation test or by that depending on the host animal species from which a certain type of these organisms is preferentially recovered (Tumansky, 1957, 1958). The latter viewpoint, which is thought to be a more practical one, has been taken by Bhatnagar (1940), Seal (1951 a, b) and Korobkova (1956), who classified P. pestis into virulent, avirulent protective and avirulent non-protective groups of strains on the basis of virulence and immunogenic properties to various experimental animals.

Jawetz and Meyer (1943) distinguished two groups of avirulent strains: the first group strains (A 1122, E.V. 51) possess a large amount of envelope antigen, i.e. Fraction I of Meyer (1950), and are also protective for mice; the second group strains (TRU, 14) are poor in envelope antigen, but protective for guinea pigs. Another group of strains which is avirulent and non-protective both for mice and guinea pigs was reported by Bhatnagar (1940), Seal (1951 a) and Amies (1951). Kasuga (1945) described that an avirulent variant, strain MII 40, had a protective power for guinea pigs and human beings from lethal infections with fully virulent plague bacilli, even though it had no detectable amount of envelope antigen.

Considering those results, the present author proposes at first the following scheme for classification of the groups or varieties of strains of $P$. pestis from the point of virulence and immunogenicity.

1. Virulent protective strains.

2. Avirulent protective strains with envelope antigen.

3. Avirulent protective strains without envelope antigen.

4. Avirulent non-protective strains.

As will be shown in the present series of papers, the interrelationship between these different groups of strains has been explained to a certain extent and some complemental corrections will be added in their conclusions. It is most conceivable from my results, that every strain of $P$. pestis can take any phase of the above varieties depending on their life history, in other words, they 
may represent each of phases of the evolutional process of plague bacilli, where the environmental factors seem to play important roles.

The present paper deals with an atypical form of $P$. pestis, which may be considered to occupy the fifth place in the above mentioned scheme of classification, with respect to lacking in the plague murine toxin which is contained in the other varieties. Evidences will be presented that this form has peculiar colonial and morphological characteristics. This form will be designated as the third colonial form of $P$. pestis hereafter, because it should be regarded as one of the phases of colonial variation such as classical smooth and rough forms, which have been customarily accepted as the representative colonial forms. Incidentally, it may be noteworthy to mention here that many practical laboratory workers dealing with plague bacilli have mistakenly recognized this form of organisms as contaminants other than $P$. pestis.

\section{Materials AND Methods}

Strains: Virulent strains, Kuma, Yokohama, and avirulent strains, E.V., Twijedej were stocks in our laboratory and have been kept on nutrient agar slants at $0^{\circ}-5^{\circ} \mathrm{C}$ with periodical passages through rats every eight weeks in order to keep their virulence constant. An avirulent strain MII40 was given by Dr. Kasuga of Kitasato Institute. Avirulent strains, A1122, E.V. 51, TRU and a virulent strain Yreka were obtained from Dr. Cavanough of the 406th General Medical Laboratory of U. S. Army and Dr. Nagao of Tokyo Quarantine Station. Our sincere thanks are due to all of them.

Media: $10 \%$ bovine blood agar and nutrient broth were used, paying causions to eliminate contaminated media by incubating the prepared media at $37^{\circ} \mathrm{C}$ overnight for sterility tests.

Guinea pigs: Guinea pigs weighing from $250 \mathrm{~g}$ to $300 \mathrm{~g}$ were used.

Mice: dd/Y strain white mice, 4 weeks old, were used.

Observation of the colonies: A bacterial suspension in nutrient broth was made with the organisms from stock slant culture to be observed. $0.1 \mathrm{cc}$ of an appropriate dilution in broth of this suspension was spread on a blood agar plate, followed by incubation at $31^{\circ} \mathrm{C}$ or at $37^{\circ} \mathrm{C}$ for two days with additional six to eight days at room temperature for the purpose of observing colonial and cellular morphology. The number of colonies formed by this procedure was approximately by $20-200$ per plate.

Glycerol-fermentation test: Peptone broth containing 1\% (w/v) Polypeptone (Takeda Pharmaceutical Industries, LTD.) and 4\% (v/v) glycerol was employed. Tumansky (1958) described glycerol-agar medium is preferable to liquid medium, because in the latter, glycerolfermentation may occasionally occur after 10-12 days' incubation. Therefore, readings of the results in this experiment were made up daily for 14 days.

Nitrates reduction test: The procedure used here was Webster's simple reaction test by employing Ilosvay's reagent (Pollitzer, 1954). One drop of a peptone broth culture grown at $37^{\circ} \mathrm{C}$ for two days was placed on a white opal glass plate and mixed with one drop of Ilosvay's reagent. The immediate appearence of red color was determined as positive.

Motility test: A semisolid medium containing $0.5 \%(\mathrm{w} / \mathrm{v})$ of agar and $1 \%(\mathrm{w} / \mathrm{v})$ of Polypeptone was stabbed with organisms of 24 hour culture on blood agar medium, followed by incubation at $22^{\circ}-25^{\circ} \mathrm{C}$. Motile strain should show characteristic fur-tree like growth in contrast to single streak-like growth of negative motility. Strain Yreka of $P$. pestis was used as a non-motile reference strain and strain Pu of $P$. pseudotuberculosis as a motile one (Seal, 1952 c).

Staining method to visuallize the bacterial envelope: Live bacilli were mixed with one drop of India ink and spread to a thin film on a slide glass with following fixation in a mixture of equal volumes of alcohol and ether. The bacterial bodies were stained out with methylene blue or with carbolfuchsin, while the area corresponding to the bacterial envelope remains white between the black background and the stained bacterial body.

Determination of the nitrogen content: The nitrogen content of the acetone-dried bacteria was determined by the micro-Kjeldahl method. 
Fraction IA as purified envelope antigen: Lyophilized preparation of Fraction $1 \mathrm{~A}$, Lot No. 278 , was kindly supplied by Dr. Meyer through Dr. Suzuki of Yokohama Quarantine Station. This preparation was extracted from the virulent strain Shasta, followed by purification by the method described by Baker et al. (1951) in Dr. Meyer's laboratories. He confirmed that it gave only one line with the whole antiplague serum by Oudin's agar diffusion precipitation test (Meyer, 1958). The same result was obtained by the present author using Ouchterlony's procedure. Preparation of Fraction IAB also was obtained from Dr. Chen (Wake, 1959b).

Preparation of the acetone-dried cells of the third colonial form: Several isolations of a single cell from the organisms of the third colonial form, derived from the subculture of strain Yokohama, were performed with the micromanipulator by Dr. Kazuo Sato of the Institute for Infectious Diseases. The isolates were enriched and cultured on the blood agar slants at $37^{\circ} \mathrm{C}$ for 24 hours, and have been kept at $4^{\circ} \mathrm{C}$ as for the stock cultures. In each experiment, one of them served as a seed culture on blood agar media. The organisms grown up were harvested in sterile saline solution contained in a centrifuge tube, and to this bacterial suspension two volumes of cold acetone were added and then the tube was placed in acetone dry-ice mixture overnight. The acetone-killed bacilli were collected by centrifugation and washed three times with acetone and then dried in vacuo.

The third form organisms derived from strain Kuma, which had been isolated by repeated selection and subcultivation of single colony, were treated in the same manner to make the acetone-dried cells.

Anti-Fraction IA serum: A total amount of $29 \mathrm{mg}$ of Fraction IA dissolved in $29 \mathrm{cc}$ of saline was injected into a rabbit intravenously six times within two weeks at intervals of two days, except at an interval of five days between the third and the fourth injections. The animal was bled two weeks following the last injection for collection of the antiserum. The antis $r$ rm was kept in a refrigerator after inactivated at $56^{\circ} \mathrm{C}$ for 30 minutes and added with a $1 \%$ solution of merthiolate in $1 \%$ by volume as a preservative. Its precipitation titer to a solution of Fraction IA $(2 \mathrm{mg} / \mathrm{cc})$ determined by ring method was $1: 64$.

Preparation of the antiserum to the third colonial form organisms (anti-third serum): The acetone-dried third colonial form organisms derived from strain Yokohama were used as an antigen, dissolving $23.7 \mathrm{mg}$ in $24 \mathrm{cc}$ of saline. The same procedure in the preparation of anti-Fraction IA serum was followed. This antiserum agglutinated the homologous strain to a titer of $1: 2^{10}$, and its precipitin titer to the extracted antigen of the homologous strain was $1: 128$. Another antiserum to the third form cells of strain Kuma was also prepared in the same way.

Preparation of the antiserum to the formalin-killed Yreka strain (anti-Yreka serum): The same procedure as in the preparation of anti-Fraction IA serum was followed except that formalin-killed plague vaccine containing $31 \mathrm{mg}$ wet bacilli of strain Yreka in $15.5 \mathrm{cc}$ of saline was used as the antigen.

Preparation of the antiserum to the live virulent strain (antiplague whole serum): In order to carry out Ouchterlony's agar diffusion precipitation technique, the antisera to the live organisms of virulent strain Yreka were prepared.

Formalin-killed vaccine was made for preliminary immunization to contain $2 \mathrm{mg}$ wet bacilli in $1 \mathrm{cc}$ of saline. Each of three rabbits received a subcutaneous injection with $1 \mathrm{cc}$ of the vaccine with further five intravenous injections of $8.5 \mathrm{cc}$ of the vaccine in total. Two weeks after the last injection of the vaccine, they were injected subcutaneously with $10^{7}$ live organisms of strain Yreka suspended in sterile saline. Afterwards, progressively increased numbers of organisms up to $2 \times 10^{9}$ were given over several weeks. Exanguinations were made after the seventh injection of the live organisms to collect the antiserum. The antiserum was stored in the refrigerator without any preservative and inactivation.

Agglutinaticn test: A two-fold serial dilution of the antiserum with saline was made in small test tubes and $0.5 \mathrm{cc}$ of the saline suspension of live bacilli at a concentration of $1 \mathrm{mg}$ of wet bacilli per cc was added to each tube. Readings were made after the tubes had been incubated in a $37^{\circ} \mathrm{C}$ water bath for 2 hours and after further standing at $4^{\circ} \mathrm{C}$ overnight. Since the result was variable, when the acetone-dried cells were used as antigen, the live bacilli of 24 hour growth suspended in saline were found to be preferable for this test.

Precipitation test: Lyophylized Fraction IA dissolved in saline at a concentration of $0.2 \mathrm{mg} / \mathrm{cc}$ was employed as Fraction IA antigen.

For the extracted antigens of whole bacilli, a suspension of organisms of 24 hour or of 48 hour growth was made to contain $10 \mathrm{mg}$ in $1 \mathrm{cc}$ of the saline containing $0.5 \%$ phenol. It 
was shaken for 30 minutes with glass beads and kept at $37^{\circ} \mathrm{C}$ for 24 hours. After this had been centrifuged, the supernatant was employed as the antigen.

Hemagglutination tests: The procedure described by Chen and Meyer (1954) was employed.

Agar diffusion precipitation technique: The technique employed here was principally the same as that described by Ouchterlony (1948).

The purified agar (Kanto-Kagaku Co. Ltd.) was dissolved in the saline containing $0.01 \%$ merthiolate at a concentration of $1.5 \%$. After the samples had been pipetted into each reservoir, the plates were placed at $37^{\circ} \mathrm{C}$ in an incubator, keeping the moisture in saturation.

Fractionation of Fraction $1 A$, Fraction $I B$ and toxin: Extraction and fractionation of antigenic components from the acetone-dried cells prepared with the third colonial form organisms, strain MII40 and Yreka were performed by using the methods described by Baker et al. (1951). The method consisted of : (1) extraction of acetone-dried cells with $2.5 \%$ sodium chloride solution containing $0.001 \mathrm{M}$ phosphate buffer at $\mathrm{pH} 7.2$, (2) dialysis of the extract against cold distilled water, (3) fractionation of Fraction IA, Fraction IB and toxin from the extract with ammonium sulfate in saturations of $0.25-0.30,0.30-0.40$ and $0.40-0.67$, respectively, at $\mathrm{pH} 7.2$ at room temperature.

Each fraction was collected by centrifugation at $22,500 \mathrm{G}$ for 40 minutes in the cold, followed by dialysis against distilled water and by drying in the frozen state in a vacuum.

Each fraction derived from various strains was named Fraction IA, Fraction IB or toxin, respectively according to the fractionation method, irrespective of the extracted strains, though samely named fractions from different strains may have not always the same components.

Determination of toxicity to mice: Groups of each 8 mice were injected intravenously with two-foldly diluted doses of various samples under tests. Although most of the deaths could be seen within 48 hours after injections, the final results were recorded after a 7 days' observation. Fifty per cent lethal dose $\left(\mathrm{LD}_{50}\right)$ was estimated by the method of Reed and Muench (1938).

Determination of virulence: A broth suspension of the live bacilli was made at a concentration of $2 \mathrm{mg} / \mathrm{cc}$. A ten-fold serial dilution was made from this with broth. Groups of mice, each consisting of 5 to 8 mice, were injected with those dilutions, each mouse receiving $0.2 \mathrm{cc}$ subcutaneously. At the same time, the viable cell count on the suspension was carried out. The mice were observed for 3 weeks. The dead was autopsied for examination of the presence of the bacilli by culturing its spleen, liver, lung and blood on blood agar slants.

Protection test: For measurement of protective power of the bacterial strains, groups of approximately 20 mice each were injected with respective sample and challenged with a virulent culture. In the case of immunizations with live bacilli, subcutaneous inoculations were given. With killed bacilli or with an antigenic substance, mice were immunized intraperitoneally. The mice were challenged by subcutaneous injections with a certain number of organisms of a fully virulent culture. The deaths were followed over 3 weeks. Further details of the methods will be described in Experimental results.

\section{RESULTS}

Colonial Characteristics of the Third Form: Colonies recognized as the third form by the present author may mainly differ by two characteristics from the ordinary colonies of plague bacilli: much faster growth and extremely opaque and white appearance (Figs. 1, 2 and 3).

The organisms of this form could form visible small colonies on agar plates even after approximately 6 hour incubation at $37^{\circ} \mathrm{C}$, when they had become well adapted to the given medium. In the earlier stage of growth, they looked like dew-drops and were transparent or slightly opaque at the center with smooth edges. In rare cases, only the outermost edges remained transparent. Fortyeight hours later, they grew up to completely white and opaque colonies with smooth and glistening surface.

In additional keeping at room temperature, they became at last "amorph" 
with development of "navel" at the center, usually after having swelled somehow round of surface.

Some varieties in color and shape may be seen besides the above typical colonial form.

Morphology of the Individual Cells of the Third Colonial Form: By examination of the individual cells of this form under the light microscope, the shape of them looked cocci-like by which one may easily distinguish organisms of this form from other plague bacilli. They had strong affinity to such stains as methylene blue or carbolfuchsin, showing staphylococci-like stained picture when stained by these stains. However, through a more precise observation, I could recognize a pair of portions near the both ends of a cell stained much more deeply than the other parts of the cells. This gave me an impression as if they were diplococci (Fig. 4).

Another important observation made by India ink method was that the cell had no part corresponding to the envelope around the bacterial body.

Growth in Liquid Media: Organisms of this form grew up with homologous turbidity in nutrient broth, while most of the typical cultures of $P$. pestis grew with precipitation remaining the supernatant clear.

Variation into the Third Colonial Form: All strains of P. pestis examined in this experiment gave rise to the third form of colonies by subculturing repeatedly on the artificial media without passage through experimental animals or simply by keeping the stock cultures at $0^{\circ}-5^{\circ} \mathrm{C}$ for several months followed by cultivation on the agar media.

For a representative example, starting from a single colony of the smooth form of strain E.V., a series of subcultivations was carried out by transferring a single colony from a culture to the next. At the eleventh subcultivation, 3 colonies of the third form were found grown up among 334 smooth form colonies.

The third form colonies could also be isolated from spleens and livers of the mice that survived from challenge of virulent strain Yokohama, or of virulent strain Yreka for more than 3 weeks in the immunization tests of dead vaccines, or of Fraction IA, by culturing them on agar media.

The other case of recovering this form will be described in the following paper (Wake, $1959 \mathrm{~d}$ ).

Biological Activities: Two strains of the third form derived from strains Kuma and Yokohama reduced nitrates to nitrites as their parent strains. However, one strain derived from glycerol-negative strain Kuma fermented glycerol after 14 days' incubation, whereas another strain from glycerol-positive strain Yokohama remained unchanged. These strains remained also non-motile.

The nitrogen content of acetone-dried cells of the third form derived from strain Kuma was $11.0 \%$, that was almost identical to the nitrogen contents of smooth and rough form cells.

Absence of Murine Plague Toxin in the Third Form: The following evidences seem to support that the organisms of the third form have no murine plague toxin. Table 1 shows the relative toxicity of strain E.V., Kuma and the third forms derived from them to mice by intravenous injections. Both strains of the third form had approximately 3 to 6 times lower toxicity than the parent strains. In comparison with a rough organism of strain Kuma whose $\mathrm{LD}_{50}$ was 
$2.3 \mathrm{mg}$, the third form strains showed also lower toxicity.

Furthermore, the mode of death caused by intravenous injection with acetonedried third forms was substantially different from that of murine plague toxin, acetone-dried rough or smooth forms. In the former case, when injected with a large amount, the mice were immediately killed after revealing shock in contrast to the death caused by murine plague toxin which occurred usually at least several hours after injection.

In the process of purification of antigenic components of the third form organisms, it was proved that the fraction which should be considered to correspond to plague toxin had no toxicity to mice. By using agar diffusion precipitation tests of Ouchterlony, no precipitation line to correspond to plague toxin was observed in the preparation of this form, as will be seen in Fig. 5.

Table 1. The relative toxicity of acetone-dried organisms of the smooth form of strains E. V. and Kuma and the third form strains derived from them

\begin{tabular}{|c|c|c|c|c|}
\hline \multirow{3}{*}{$\begin{array}{l}\text { Dose injected } \\
\text { per mouse }\end{array}$} & \multicolumn{4}{|c|}{ Strain } \\
\hline & \multicolumn{2}{|c|}{ E. V. } & \multicolumn{2}{|c|}{ Kuma } \\
\hline & S-form* & 3 -form** & S-form* & 3-form** \\
\hline $20 \mathrm{mg}$ & & $8 / 8^{+}$ & & $8 / 8$ \\
\hline 10 & & $8 / 8$ & & $6 / 8$ \\
\hline 5 & $8 / 8$ & $0 / 8$ & $8 / 8$ & $2 / 8$ \\
\hline 2.5 & $7 / 8$ & & $4 / 8$ & $0 / 8$ \\
\hline 1.25 & $0 / 8$ & & $0 / 8$ & \\
\hline $\mathrm{LD}_{50}(\mathrm{mg})$ & 1.9 & 12.6 & 2.5 & 7.1 \\
\hline Relative toxicity & 1.0 & 6.5 & 1.3 & 3.5 \\
\hline
\end{tabular}

Absence of Envelope Antigen (Fraction I) in the Third Colonial Forms: Another important finding on the antigenic components of the third form was the complete lack in envelope antigen (Fraction IA and Fraction IB of Meyer's fractions) that can be conceivable from the following evidences.

The ring precipitation tests between anti-third serum prepared with a strain derived from strain Yokohama and the reference standard of Fraction IA, and vise versa, turned out completely negative, indicating that the third form organisms had no Fraction IA.

The same negative results were obtained by hemagglutination test using Fraction IB as antigen. At first, hemagglutination test was carried out between the anti-third serum (Yokohama) and sheep red blood cells sensitized with the purified Fraction IB, but there did not appear any positive agglutination. Secondly, certain portions of antisera against Fraction IA and formalin-killed 
organisms of strain Yreka were absorbed twice by adding large amounts of organisms of the third form cultured for 48 hours at $37^{\circ} \mathrm{C}$ and by incubating at $37^{\circ} \mathrm{C}$ for 3 hours at each time with following holding at: $4^{\circ} \mathrm{C}$ overnight. The non-absorbed antisera and the absorbed antisera were titrated with sheep red blood cells sensitized with the purified Fraction IB as antigen. The titers of the antisera did not show any decrease by the absorptions. The data are presented in Table 2.

Table 2. Hemagglutination tests showing the absence of envelope antigen (Fraction I in the organisms of the third colonial form (Yokohama-third-form) by using the sheep red blood cells sensitized with the purified Fraction IB

\begin{tabular}{|c|c|c|c|c|c|}
\hline \multirow{3}{*}{$\begin{array}{l}\text { Dilutions of } \\
\text { antiserum }\end{array}$} & \multicolumn{5}{|c|}{ Antisera } \\
\hline & \multirow{2}{*}{$\frac{\begin{array}{c}\text { Anti-third- } \\
\text { serum }\end{array}}{\text { Non-absorbed }}$} & \multicolumn{2}{|c|}{ Anti-Fraction IA-serum } & \multicolumn{2}{|c|}{ Anti-Yreka-serum } \\
\hline & & $\begin{array}{c}\text { Before } \\
\text { absorption }\end{array}$ & $\begin{array}{c}\text { After } \\
\text { absorption }\end{array}$ & $\begin{array}{c}\text { Before } \\
\text { absorption }\end{array}$ & $\begin{array}{c}\text { After } \\
\text { absorption }\end{array}$ \\
\hline $1: 2$ & $-^{+}$ & $2+$ & $\mathrm{n}^{*}$ & $4+$ & $\mathrm{n}$ \\
\hline 1: 4 & - & $2+$ & $4+$ & $3+$ & $4+$ \\
\hline $1: 8$ & - & $2+$ & $2+$ & $3+$ & $3+$ \\
\hline $1: 16$ & - & + & $2+$ & $3+$ & $2+$ \\
\hline $1: 32$ & - & + & + & $3+$ & $2+$ \\
\hline $1: 64$ & - & \pm & \pm & + & + \\
\hline $1: 128$ & - & - & - & \pm & \pm \\
\hline $1: 256$ & - & - & - & - & - \\
\hline Saline & - & - & - & - & - \\
\hline
\end{tabular}

+ Nagative hemagglutination was recorded: - . Positive hemagglutination were recorded: extremely strong, $4+$; very strong, $3+$; strong, $2+$; clearly positive, + ; doubtful, \pm

* $\mathrm{n}$ means not done.

Although in the fractionating processes of Fraction IA and IB from $10 \mathrm{~g}$ of acetone-dried organisms of the third form, a negligible amount of substance was obtained, they could not be identified as Fraction IA or Fraction IB because the corresponding precipitin tests showed negative results.

In Ouchterlony's tests also, there did not appear any precipitation line that could be defined as Fraction I between the preparations of the third form organisms and the antiserum to the live virulent strain Yreka (Fig. 6). All lines between them cross the line between the Fraction I and anti-live-Yreka serum.

Somatic Antigens: Further observation on the antigenic components of this form confirmed that it shared at least 2 common somatic antigens with other plague bacilli; for example, strain Yreka and avirulent strain MII 40.

Antibody Formation in the Rabbit: The injections of acetone-dried cells of the third form derived from strain Yokohama into rabbits stimulated formation of antibodies against this form which were detected by agglutination reaction and by precipitation reactions. 
Virulence: The results obtained from virulence tests of strains of the third form are presented in Table 3.

This indicates that this form had low virulence to mice. In this experiment, it may be of interest that the revertant cells to the smooth or rough forms of parent strains were detected from some of killed mice by culturing their organs on blood agar media.

Table 3. Virulence tests of strains of the third colonial form to mice

\begin{tabular}{|c|c|c|c|c|c|c|c|c|c|c|c|}
\hline \multicolumn{12}{|c|}{ Strain number* } \\
\hline \multicolumn{2}{|c|}{ Kuma-1 } & \multicolumn{2}{|c|}{ Kuma-2 } & \multicolumn{2}{|c|}{ Kuma-3 } & \multicolumn{2}{|c|}{ Yokohama-1 } & \multicolumn{2}{|c|}{ Yokohama-2 } & \multicolumn{2}{|c|}{ Yokohama-3 } \\
\hline \multirow[t]{3}{*}{$\begin{array}{l}\text { No. of } \\
\text { bacilli } \\
\text { inoc. } \\
(3.6 \times)\end{array}$} & $\begin{array}{c}\text { death/** } \\
\text { total }\end{array}$ & $\begin{array}{l}\text { No. of } \\
\text { bacilli } \\
\text { inoc. } \\
(1.0 \times)\end{array}$ & $\begin{array}{l}\text { death/ } \\
\text { total }\end{array}$ & $\begin{array}{l}\text { No. of } \\
\text { bacilli } \\
\text { inoc. } \\
(1.0 \times)\end{array}$ & $\begin{array}{l}\text { death/ } \\
\text { total }\end{array}$ & $\begin{array}{l}\text { No. of } \\
\text { bacilli } \\
\text { inoc. } \\
(3.4 \times)\end{array}$ & $\begin{array}{c}\text { death/ } \\
\text { total }\end{array}$ & $\begin{array}{l}\text { No. of } \\
\text { bacilli } \\
\text { inoc. } \\
(5.2 \times)\end{array}$ & $\begin{array}{c}\text { death/ } \\
\text { total }\end{array}$ & $\begin{array}{l}\text { No. of } \\
\text { bacilli } \\
\text { inoc. } \\
(2.9 \times)\end{array}$ & $\begin{array}{c}\text { death/ } \\
\text { total }\end{array}$ \\
\hline & & & & $10^{9}$ & $4 / 8$ & & & & & & \\
\hline & & $10^{8}$ & $0 / 8$ & $10^{8}$ & $0 / 8$ & & & & & & \\
\hline $10^{7}$ & $0 / 8$ & $10^{7}$ & $2 / 8^{+}$ & $10^{7}$ & $0 / 8$ & $10^{7}$ & $3 / 8^{+}$ & & & $10^{7}$ & $0 / 8$ \\
\hline $10^{6}$ & $0 / 8$ & $10^{6}$ & $0 / 8$ & & & $10^{6}$ & $1 / 8^{+}$ & $10^{6}$ & $1 / 8^{+}$ & $10^{6}$ & $0 / 8$ \\
\hline $10^{5}$ & $0 / 8$ & $10^{5}$ & $0 / 8$ & & & $10^{5}$ & $1 / 8^{+}$ & $10^{5}$ & $1 / 8^{\#}$ & $10^{5}$ & $0 / 8$ \\
\hline $10^{4}$ & $0 / 8$ & & & & & $10^{4}$ & $0 / 8$ & $10^{4}$ & $0 / 8$ & $10^{4}$ & $0 / 8$ \\
\hline $10^{3}$ & $0 / 8$ & & & & & $10^{3}$ & $0 / 8$ & $10^{3}$ & $2 / 8^{+}$ & $10^{3}$ & $2 / 8^{\#}$ \\
\hline \multirow[t]{3}{*}{$10^{2}$} & $0 / 8$ & & & & & $10^{2}$ & $0 / 8$ & $10^{2}$ & $0 / 8$ & $10^{2}$ & $1 / 8^{+}$ \\
\hline & & & & & & $10^{1}$ & $0 / 8$ & $10^{1}$ & $0 / 8$ & $10^{1}$ & $0 / 8$ \\
\hline & & & & & & $10^{\circ}$ & $0 / 8$ & $10^{\circ}$ & $0 / 8$ & $10^{\theta}$ & $0 / 8$ \\
\hline
\end{tabular}

\footnotetext{
* Kuma-1 was isolated by repeated subcultivations of strain Kuma. Kuma-2 and Kuma-3 were recovered from cultures of strain Kuma by prolonged keeping at $4^{\circ} \mathrm{C}$.

Yokohama-1, $-2,-3$ were isolated from absesses of the spleens of mice that survived from experimental plague.

** The number of killed mice presented here is the total for 21 days observation.

+ From these killed mice, smooth form colonies were isolated at autopsy.

* From these killed mice, rough form colonies were isolated at autopsy.
}

Protection Test: The active protection tests of mice with the third form strains showed that they had no protective power to those animals against the challenges of virulent organisms. The results are presented in Tables 4 and 5 . More detailed studies on this aspect will be described in the following papers (Wake, 1959 b, e).

Stability of the Third Colonial Form: The bacilli of the third colonial form seemed extremely stable while growing on the artificial media, in respect to variation to undergo to the other colonial phases.

However, as mentioned above, the possible revertant cells to the parent phases were detected from the organs of the mice which had been killed by the inoculation with the organisms of the third form in the virulence tests. This phenomenon was further confirmed by isolating smooth form bacilli from the mice used in short time passage experiments by inoculating the third form 
Table 4. Active protection tests of mice with Yokohama-third-form, Fraction IA and standard reference vaccine made of strain Yreka

\begin{tabular}{lc}
\hline Immunized with & Survival/Total \\
\hline Killed y-3-f* & $6 / 25$ \\
Fraction IA & $21 / 25$ \\
Killed Yreka* & $13 / 25$ \\
Control & $6 / 25$ \\
\hline
\end{tabular}

Immunizing injections were given intraperitoneally twice at an interval of 7 days with the following doses : acetone-killed Yokohama-third-form bacilli, each $0.3 \mathrm{mg}$; Fraction IA, each $6 \mu \mathrm{g}$; standard reference vaccine of strain Yreka, each $0.4 \mathrm{mg}$ wet bacilli. Challenge injections were given with 10 organisms of virulent strain Yreka 7 days after the last immunization.

*Killed $y-3-f$ means killed organisms of Yokohama-third-form.

Killed Yreka means the standard reference vaccine made of formalin-killed organisms of strain Yreka.

bacilli from mice to mice. Detailed results are described in other reports (Wake, $\left.1958^{*}, 1959 \mathrm{e}\right)$.

Attempts were made to elucidate the governing factors of the variation from the third form to the other forms of plague bacilli employing passages through chick embryo or cultivation under the increased carbon dioxide pressures, but any conclusive results could not be obtained.

In the latter attempt, it was succeeded to find much more transparent and smooth colonies after several subcultivations of the third form bacilli under conditions of increased carbon dioxide pressures on artificial media. But, they could not be stabilized so as to yield any conclusion on the mechanism of variation.

\section{Discussion}

A new colonial form, designated by me as the third colonial form, has such different characteristics that it can possibly be distinguished from the other

Table 5. Active protection test of mice with live organisms of Yokohama-third-form

\begin{tabular}{cc}
\hline $\begin{array}{c}\text { Number of bacilli immunized } \\
(2.9 \times)\end{array}$ & Survival/Total \\
\hline $10^{7}$ & $2 / 8$ \\
$10^{6}$ & $2 / 8$ \\
$10^{5}$ & $0 / 8$ \\
$10^{4}$ & $1 / 8$ \\
\hline ED $_{50}$ & $>2.9 \times 10^{7}$ \\
\hline
\end{tabular}

Immunizing injections were given subcutaneously. Challenge injections were given with 10 organisms of virulent strain Yreka, 27 days after immunization.

The challenge control group was the same as in Table 4.

*In this paper, the third colonial form was erroneously designated as smooth and the mooth form as rough. 
forms or varieties of $P$. pestis. Namely, this form organisms have specific colonial and morphological characters and antigenic structures, though it retains somatic antigens and non-motility common to the organisms of this species.

As far as literatures surveyed by the present author are concerned, there has not been any description clearly stated about a form corresponding to the third form.

In the monograph of Pollitzer (1954), no description about the organisms resembling the third form was found. Korobkova (1956) described that the plague bacilli can variate from the rough form to the smooth form, further becoming more "saprophitized" form under conditions cultured in vitro. However, there is no description about the biological characters of her "saprophitized" form in this paper.

Tumansky (1958) did not describe the organisms to be considered in my third form. Bhatnagar (1940) reported on the pneumococci-like fat organisms and the other varieties which lack visible envelope by the observation employing the Incia ink method. These organisms belonged to the opaque colony with raised center according to his classification of plague colonies. Seal (1951 a) also found envelope lacking forms, which were not cocci-like in shape but had elongated shape, though they had strong affinity for fuchsin. Amies (1951) reported that repeated subcultivations eventually gave rise to dissociative changes irrespective of the type of the culture medium used. The change to the noncapsulated type was heralded by the appearance of large ovoid cell with a strong affinity for fuchsin.

At least a part of these descriptions seems to be in accord with the characters of the third form described here. The organisms of the third form, however, can be regarded as one of the independent forms of $P$. pestis, because of their stable and specific natures. It would be most conceivable that the discrepancies of the characters between the third form and the smooth or rough form are much greater than the differences between the rough and smooth forms of $P$. pestis, if one takes into consideration the lacks of envelope antigen and murine toxin in the third form bacilli. In this connection, it would be reasonable to encounter the non-protective and avirulent natures of this form for mice and guinea pigs to the antigenic structure, i.e., the complete lacking in envelope antigen and plague murine toxin which are believed to play main roles in protective power and virulence of $P$. pestis. Concerning with the immunogenicity of this form, more detailed studies have been made by comparing it with the avirulent strain MII40, which will be reported in the following paper (Wake, 1959 b).

As an addition of such detailed studies to the scheme hypothetically presented by present author in the section of Introduction, it must be supplemented by the fifth avirulent non-protective strains which have neither envelope nor murine plague toxin, namely, third colonial forms of various strains. It can not occupy the fourth position because avirulent non-protective strains with envelope or murine plague toxin can occur.

The next points to be worth to discuss here is the variability of this form. In general, many authors who have dealt with plague bacilli do not seem to believe the reverse mutation of mutant forms. Amies (1951), for example, des- 
cribed that the large ovoid fuchsin-affinitive variant never showed back mutation. Jackson and Burrows (1956 a) reported that a non-pigmentating colony was never seen to mutate to pigmentating colony. Back mutation from variants which ferment rhamnose to non-fermentative is hardly believed. Likewise, the third colonial form was never observed to undergo variation into the other forms under usual conditions on artificial media, unless being repeatedly passed through the non-immunized mice.

This fact would suggest a possible role of host animals in the evolutionary process of plague bacilli.

On one hand, some workers of plague bacilli have the opinion that these bacilli can variate to Pasteurella pseudotuberculosis beyond the border-line of species. The species-forming variation, which includes the above opinion, has been one of the problems about which T. D. Lysenko and his antagonists have been discussing. On the other hand, however, the above opinion is denied by the other schools of workers.

According to the observations reported in this paper, the ordinary forms of $P$. pestis undergo variation to the third form which has not only fast-growing ability on the artificial media as $P$. pseudotuberculosis, but also has only the somatic antigens common to $P$. pseudotuberculosis. Therefore, one cannot deny the above mentioned theory of species-forming variation in the case of variations of $P$. pestis without any consideration, but much more concrete and extensive studies have to be done before reaching to accept such a theory. In the practical meaning of this third colonial form, one must remember that it can be recovered from animals that survived after plague infection. The danger of this form to become origin for epidemic or epizootic is, in all probability, very little. In this connection, too, the study of bacterial variation in plague is important.

\section{SUMMARY}

The morphological and immunological characteristics of one of the colonial forms of Pasteurella pestis were described. This colonial form is considered to be one of variational phases of this organism along with classical smooth and rough forms and has been designated as "the third colonial form" by the present author.

The typical colony of the third form on agar media has smooth surface and margine and is white and non-transparent in color. The individual cell shows cocci-like shape with strong affinity for fuchsin and methylene blue by staining.

The organisms of this form is avirulent and non-protective, lacking in both the envelope antigen and the plague murine toxin.

There is little doubt to believe that any strain of $P$. pestis can undergo variation to the third form on artificial media under certain conditions.

Isolation of the third form organisms from immune animals survived from challenge with a virulent cultures was also possible. Induced variation to the other forms such as smooth or rough from the third colonial form has been very $1 t$, if not impossible, although some experiments have been attempted to elicidate the governing factors of this variation. 
The colonial forms resembling the third colonial form described in the earlier literatures by several authors have been compared with this form and discussed.

The author is indebted to Dr. K. F. Meyer and Dr. T. H. Chen, Hooper Foundation of California University, U. S. A. and Dr. K. Sato, Institute for Infectious Diseases, Tokyo University for supplementation of biological preparations and technical assistance, to Dr. Rintaro Nakaya, Department of Bacteriology, National Institute of Health, Tokyo, for revising the manuscript, to Mr. H. Kaneko and Mrs. T. Tomita for technical assistance in carrying out the work described. The author thanks Dr. Hideo Fukumi, Chief of the Department of Bacteriology, National Institute of Health, Tokyo, for his sustained interest in this research project.

\section{REFERENCES}

Amies, C. R. (1951): The envelope substance of Pasteurella pestis. Brit. J. Exper. Path., $32,259-273$.

Baker, E. E., Sommer, H., Foster, L. E. Meyer, E. \& Meyer, K. F. (1951): Studies on immunization against plague I. The isolation and characterization of the soluble antigen of Pasteurella pestis. J. Immunol., 68, 131-145.

Bhatnagar, S. S. (1940): Bacteriological studies on Pasteurella pestis and Pasteurella pseudotuberculosis. I. The morphology, the growth and the dissociation of Pasteurella pestis. Indian J. M. Res., 28, 1-15.

CHEN, T. H. \& MEyer, K. F. (1954): Studies on immunization against plague: VII. A hemagglutination test with the protein fraction of Pasteurella pestis. J. Immunol., 72, 282-298.

CRumpton, M. J. \& Davies, D. A. L. (1956): An antigenic analysis of Pasteurella pestis by diffusion of antigens and antibodies in agar. Proc. Roy. Soc. London, $B$ 145, 109-134.

JACKSON, S. \& BURROWS, T. W. (1956a): The pigmentation of Pasteurella pestis on a defined medium containing haemin. Brit. J. Exper. Path., 37, 570-576.

JACKSON, S. \& BURROWS, T. W., (1956 b): The virulence enhancing effect of iron on nonpigmented mutants of virulent strains of Pasteurella pestis. Brit. J. Exper. Path., 37, 577-583.

JAWETZ, E. \& MEyer, K. F. (1943): Avirulent strains of Pasteurella pestis. J. Infect. Dis., $73,124-143$.

KASUGA, T. (1945): [The study about the immunization against plague by living bacilli]. "Nihonigaku oyobi Kenkohoken", No. 3213, 1053-1058 (text in Japanese).

KOROBKOVA, E. I. (1956): [Living antiplague vaccines], p. 205, Gosudarstvennoe Izdatel'stvo Meditzinskoi Literatury, Moscow (text in Russian).

MEYER, K. F. (1950): Immunity in plague: A critical consideration of some recent studies. J. Immunol., 64, 139-163.

MEYER, K. F., (1958): Personal communication.

OUCHTERLONY, O. (1948): Antigen-antibody reactions in gels. Arkiv Kemi Mineral. Geol., $B$ 26, No. 14, 1-9.

Pollitzer, R. (1954): Plague, p. 698, World Health Organization, Geneva.

REed, L. J. \& Muench, H. (1938): A simple method of estimating 50\% end points. Am. J. Hyg., 27, 493-497.

SEAL, S. C. (1951 a): Studies in Pasteurella pestis, Pasteurella pseudotuberculosis and their variants. I. Growth, morphology, salt stability and biochemical reactions. Ann. Biochem. Exper. Med., 11, 130-142.

SEAL, S. C. (1951 b): Studies in Pasteurella pestis, Pasteurella pseudotuberculosis and their variants. II. Serology-agglutination, cross agglutination, absorption and crossabsorption of agglutinins. Ann. Biochem. Exper. Med, 11, 143-170.

SEAL, S. C. (1951 c): Studies in Pasteurella pestis, Pasteurella pseudotuberculosis and their 
variants. III. Serology-precipitation. Ann. Biochem. Exper. Med., 11, 171-180.

SEAL, S. C. (1952): A note on the methods for the differentiation of Pasteurella pestis and Pasteurella pseudotuberculosis. Ann. Biochem. Exper. Med., 12, 123-134.

Spivack, M. L., Foster, L., Larson, A., Chen, T. H., Baker, E. E. \& Meyer, K. F. (1958): The immune response of the guinea pig to the antigens of Pasteurella pestis. J. Immunol., 80, 132-141.

TumANSKY, V. M. (1957): [On the classification of the sub-species of plague bacilli]. J. Microb. Epidem. \& Immunobiol., No. 6. 1-7 (text in Russian).

TUMANSKY, V. M. (1958); [Microbiology of plague] 2nd Ed. p. 266. Gosudarstvennoe Izdatel'stvo Meditzinskoi Literatury, Moscow (text in Russian).

WAKE, A. (1957): [The variation of plague pathogen (Strain E.V.) in the organisms of white mice]. J. Microb. Epidem. \& Immunobiol., No. 12, 123-126 (text in Russian).

WAKE, A. $(1959 \mathrm{~b})$ : Some aspects of variations of Pasteurella pestis. II. Comparative study of strain MII40 with the third colonial form of Pasteurella pestis. Jap. J. M. Sc. \& Biol., 12, 55-69.

WAKE, A $(1959 \mathrm{c})$ : Some aspects of variations of Pasteurella pestis. III. The L-form of Pasteurella pestis in the host organisms, to be published.

WAKE, A., (1959 d) : to be published.

WAKE, A., (1959 e) : to be published. 


\section{Explanation of Figures}

Fig. 1. Typical colonies of the third colonial form of $P$. pestis grown on a blocd agar plate at $37^{\circ} \mathrm{C}$ for 48 hours. ( $\times 5$ Magnif.)

Fig. 2. Typical colonies of the rough form of $P$. pestis strain Yokohama grown on a blood agar plate at $37^{\circ} \mathrm{C}$ for 48 hours. ( $\times 5$ Magnif.)

Fig. 3. Colonies of the third colonial form and the smooth form of P. pestis. A mouse survived from experimental infection with the organisms of a virulent strain Yokohama was autopsied and a sample from the absecess of its spleen was streaked on a blood agar plate with following incubation at $37^{\circ} \mathrm{C}$ for 24 hours. Few transparent smooth colonies are seen among white third form colonies. ( $\times 5$ Magnif.)

Fig. 4. The bacilli of the third colonial form derived from $P$. pestis strain Yokohama stained with methylene blue. ( $\times 500$ Magnif.)

Fig. 5. A diffusion plate showing the absence of plague murine toxin in the organisms of the third colonial form. Reservoir G contains antiplague whole serum. Reservoir A contains $20 \mathrm{mg} / \mathrm{cc}$ suspension of acetone-dried cells of Yokohama-third-form. Reservoir B contains $20 \mathrm{mg} / \mathrm{cc}$ suspension of acetone-dried cells of strain Yreka. Reservoir C contains $20 \mathrm{mg} / \mathrm{cc}$ solution of Fraction IA, Lot No. 278. Reservoir D contains $8 \mathrm{mg} / \mathrm{cc}$ solution of the preparation corresponding to toxin fraction from the third colonial form. Reservoir E contains $20 \mathrm{mg} / \mathrm{cc}$ solution of partially purified toxin from strain Yreka. Reservoir F contains $20 \mathrm{mg} / \mathrm{cc}$ suspension of acetone-dried cells of Yreka-third-form.

Fig. 6. A diffusion plate showing the absence of Fraction $I$ in the organisms of the third colonial form. Reservoir G contains antiplague whole serum. Reservoir A contains $20 \mathrm{mg} / \mathrm{cc}$ suspension of acetone-dried cells of Yokohama-third-form. Reservoir B contains $20 \mathrm{mg} / \mathrm{cc}$ suspension of formalin-killed cells of strain Yreka. Reservoir C contains $20 \mathrm{mg} / \mathrm{cc}$ solution of Fraction IAB. Reservoir E contains $20 \mathrm{mg} / \mathrm{cc}$ solution of partially purified toxin from strain Yreka. Reservoirs D contain $20 \mathrm{mg} / \mathrm{cc}$ suspension of acetone-dried cells of transparent $\mathrm{S}$-form and R-form reverted from Kuma-third-form (to be discussed in Wake, 1959 e). 


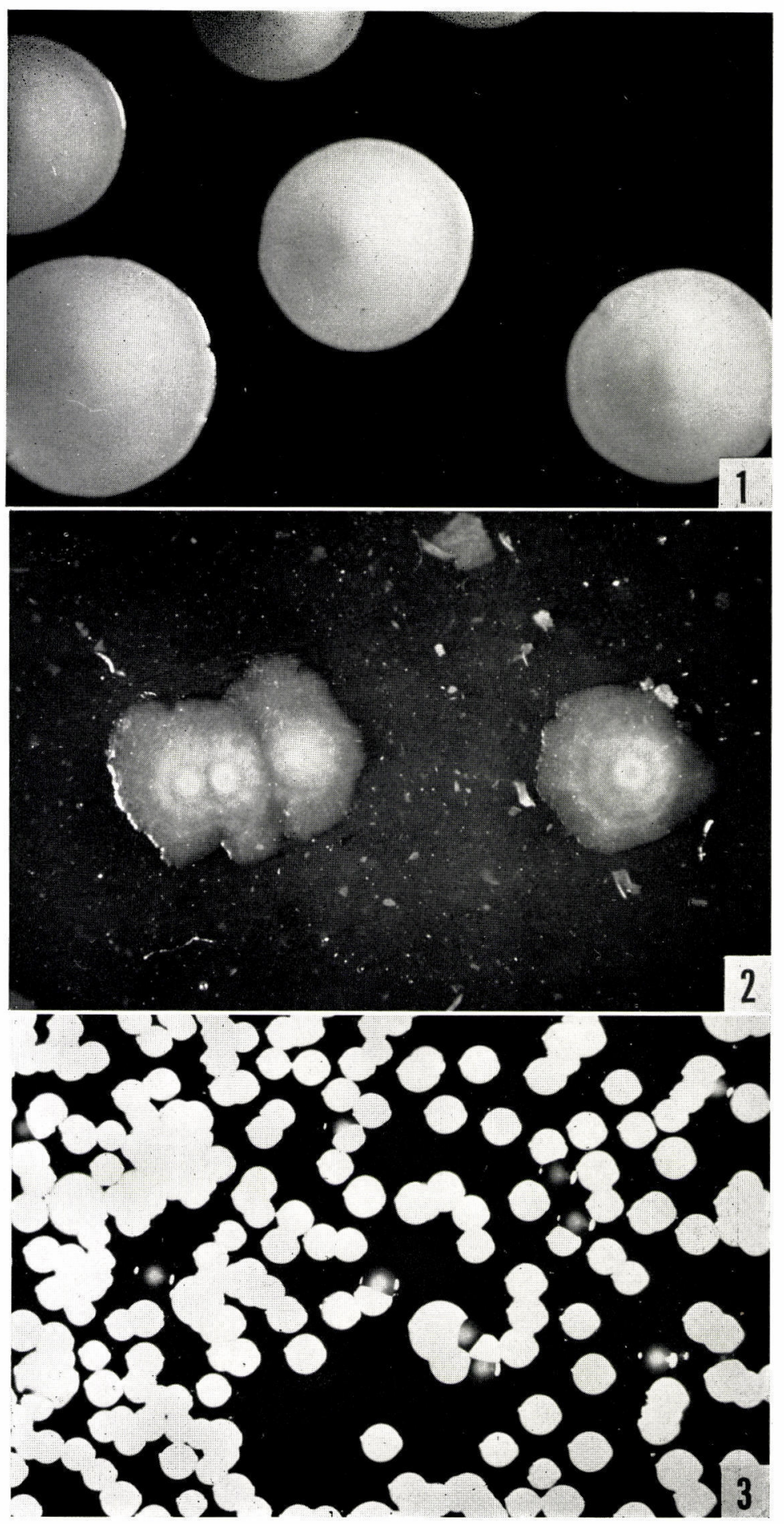




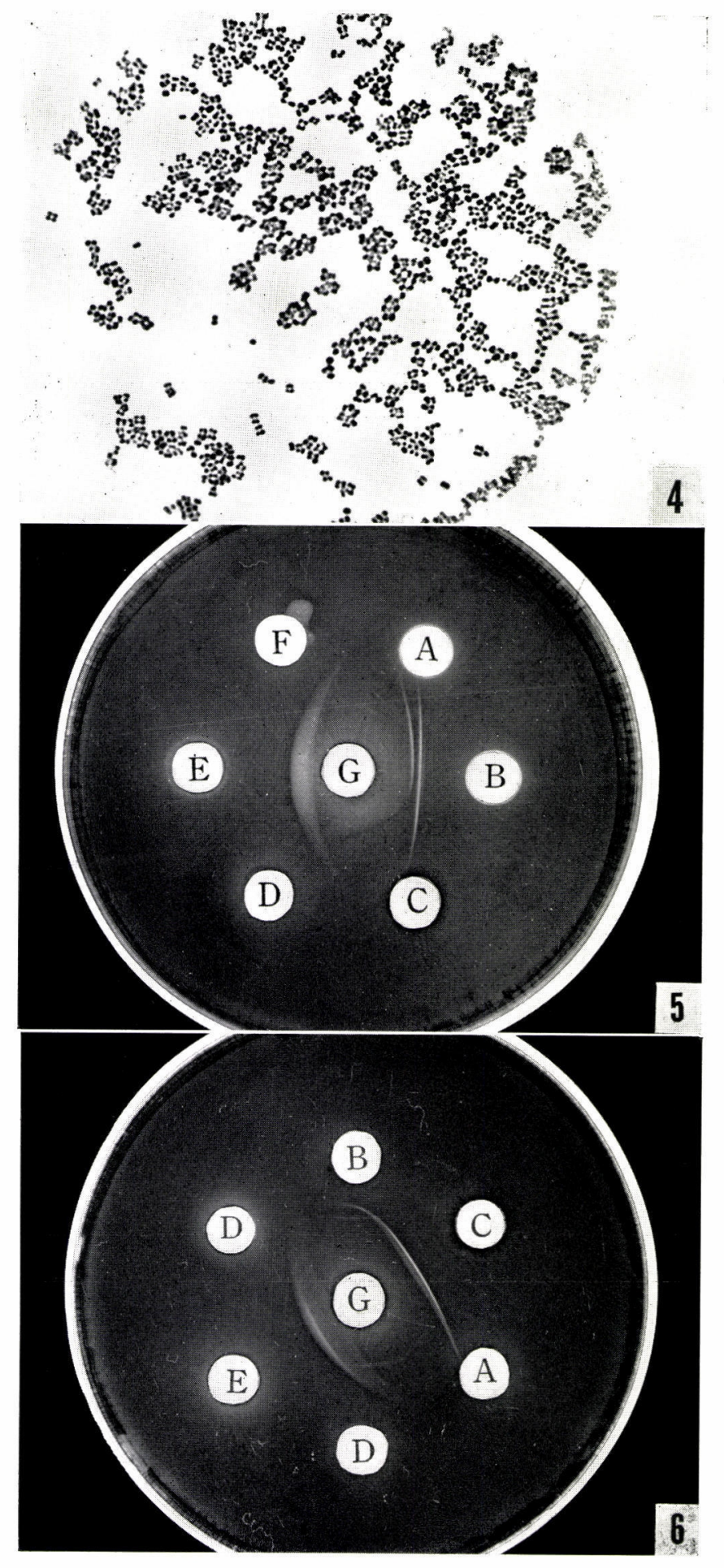

